\title{
PENERAPAN PENDEKATAN CONTEXTUAL TEACHING AND LEARNING SEBAGAI UPAYA MENINGKATKAN PRESTASI BELAJAR MATEMATIKA SISWA
}

\author{
Silviana Maya P. \\ Universitas PGRI Adi Buana Surabaya \\ smaya@unipasby.ac.id
}

\begin{abstract}
Classical learning with teacher-centered is regarded as one of the causative factors of low mathematics learning achievement of 11th grade of KR 2 students in SMKN 8 Surabaya. Hence, teachers are required to find and get someway which can reform learning motivation of students. One alternative ways that can be used is by applying Contextual Teaching and Learning approach. This research is a PTK with two cycles, that each cycle has four stages. From the analysis results, it was found that the students' learning outcomes have been classically improved from first to the second cycle. In the first cycle the percentage of students' learning success reached $58.62 \%$. At the same time, in the second cycle, it increased up to $86.20 \%$. Therefore, it can be concluded that the Contextual Teaching and Learning Approach can upgrade the mathematics learning achievement of student, and can be used as an alternative way in learning mathematics.
\end{abstract}

Keywords: Contextual Teaching and Learning Approach, mathematic learning achievement.

\section{PENDAHULUAN}

Pembelajaran secara klasikal dengan setting teacher centered masih dominan dilaksanakan di lembagalembaga pendidikan di Indonesia. Akibatnya sistem komunikasi yang terjadi cenderung satu arah, sehingga tanggung jawab siswa dalam hal kemampuan mengembangkan, menemukan, menyelidiki, dan mengungkapkan pengetahuannya menjadi berkurang.

Selain itu pembelajaran selama ini lebih berorientasi kepada kognitif siswa yang diukur dengan penilaian, sehingga siswa lebih mengedepankan hafalan dengan mengumpulkan angka setinggi-tingginya dengan cara apapun tanpa memahami makna apa yang mereka dapat untuk digunakan dalam kehidupan mereka, akibatnya siswa merasa kesulitan mengaplikasikan pengetahuan yang diperoleh dalam dunia nyata.

Hal-hal tersebut merupakan salah satu faktor utama yang menyebabkan rendahnya hasil belajar siswa pada bidang studi matematika, kondisi ini juga terjadi di SMK Negeri 8 Surabaya. Oleh sebab itu, untuk mengantisipasi timbulnya masalah di atas guru dituntut mencari dan menemukan, suatu cara yang dapat menumbuhkan kembali motivasi belajar siswa.

Guru diharapkan mampu mengembangkan suatu model pembelajaran yang dapat meningkatkan kemampuan menemukan, menyelidiki, mengembangkan dan menggunakan ide siswa sendiri, sehingga siswa tidak lagi hanya datang, duduk, mendengarkan, menjawab pertanyaan yang diberikan guru dan mencatat materi pelajaran.

Salah satu alternatif pembelajaran Matematika yang dapat dipakai adalah pembelajaran dengan pendekatan kontekstual.

Pembelajaran dengan pendekatan kontekstual (Contextual Teaching and Learning) merupakan konsep pembelajaran yang membantu guru mengaitkan antara materi yang diajarkan dengan situasi dunia nyata dan mendorong peserta didik membuat hubungan antara materi yang diajarkannya dengan penerapannnya dalam kehidupan mereka sebagai anggota keluarga dan masyarakat. (Nurhadi. 2004: 1) 
Berdasarkan latar uraian di atas maka rumusan masalah dalam penelitian ini adalah, "Apakah dengan pendekatan Contextual Teaching And Learning dapat meningkatkan Prestasi belajar Matematika Siswa Kelas XI KR 2 SMK Negeri 8 Surabaya?” yang hasilnya diharapkan dapat bermanfaat bagi guru guna meningkatkan prestasi belajar peserta didik. Dengan demikian, penelitian ini bertujuan untuk melihat ada tidaknya peningkatan pada prestasi belajar matetmatika siswa Siswa Kelas XI KR 2 SMK Negeri 8 Surabaya.

\section{METODE PENELITIAN}

Penelitian ini merupakan Penelitian Tindakan Kelas (PTK) yang dilakukan dalam beberapa siklus. Setiap siklus terdiri atas dua kali pertemuan. Pertemuan kedua merupakan kelanjutan dari pertemuan pertama. Setiap pertemuan direncanakan dengan durasi waktu 2 x 40 menit. Namun demikian, sebelum siklus dilakukan, peneliti melakukan observasi awal guna menentukan tindakan apa yang tepat untuk mengatasi masalah yang dihadapi.

Teknik pengumpulan data yang digunakan dalam penelitian ini adalah metode dokumentasi dan tes.

Data yang telah diproleh kemudian di analisis dan dilakukan penarikan kesimpulan. Adapun hal-hal yang perlu dianalisis adalah:

\section{Menilai Rata-rata Kelas}

Untuk mengetahui nilai rata-rata suatu kelas dapat dilakukan dengan menggunakan rumus berikut:

$$
\bar{x}=\frac{\sum x}{N}
$$

\section{Dengan: $\bar{x}$ adalah nilai rata-rata}

$$
\sum x \text { adalah jumlah semua nilai siswa }
$$

\section{Menilai Ketuntasan Belajar}

Terdapat 2 kategori ketuntasan belajar yaitu ketuntasan belajar individu dan ketuntasan belajar klasikal. Seorang siswa dikatakan tuntas belajar apabila mencapai Kriteria
Ketuntasan Minimal (KKM), dan kelas tersebut dikatakan tuntas apabila persenatse siswa yang memperoleh nilai lebih besar dari KKM di kelas tersebut mencapai $85 \%$.

Adapun Kriteria Ketuntasan Minimal (KKM) untuk mata pelajaran matematika di SMK Negeri 8 Surabaya adalah $\geq 70$.

Untuk menghitung persentase ketuntasan belajar di kelas digunakan rumus:

$$
E=\frac{n}{N} \times 100 \%
$$

Dengan: E : persentase ketuntasan belajar secara klasikal.

$\mathrm{n}$ : Jumlah siswa yang belajar tuntas.

$\mathrm{N}$ : Jumlah seluruh siswa.

Apabila dalam siklus pertama persentase siswa yang mendapat nilai di atas KKM (yaitu nilai $\geq 70$ ) belum mencapai 85\%, maka akan dilakukan siklus kedua, demikian pula selanjutnya. Siklus dilakukan sebanyak yang diperlukan sampai mencapai ketuntasan belajar yang diharapkan.

\section{HASIL PENELITIAN}

Dari kegiatan observasi awal diketahui bahwa kemampuan siswa kelas $\mathrm{XI}$ Kr 2 terhadap pelajaran matematika tergolong rendah, yang diketahui dari dokumentasi nilai matematika.

\section{Hasil Tes Siswa Pada Pra Siklus}

\begin{tabular}{|c|l|c|}
\hline No & \multicolumn{1}{|c|}{ Uraian } & Hasil \\
\hline 1 & Nilai rata-rata tes & 56,62 \\
\hline 2 & Persentasi ketuntasan belajar & $24,13 \%$ \\
\hline 3 & Jumlah siswa yang belajar tuntas & 7 \\
\hline 4 & Jumlah siswa yang tidak tuntas & 22 \\
\hline
\end{tabular}

Dari tabel di atas dijelaskan bahwa nilai rata-rata siswa 56,62 dan ketuntasan belajar mencapai 24,13\%.

Penelitian ini dilaksanakan dalam dua siklus. Setiap siklus terdiri atas 4 tahapan, yakni:

a. Tahap perencanaan, peneliti menyiapkan segala perangkat pembelajaran yang dibutuhkan, terkait 
dengan materi dan model serta pendekatan yang akan diterapkan di kelas.

b. Tahap kegiatan / Pelaksanaan, dalam kegiatan ini peneliti bertindak sebagai penyampai materi pelajaran sekaligus pengamat yang dibantu pula oleh teman sejawat. Adapun proses belajar mengajar mengacu pada rencana pembelajaran yang telah dipersiapkan.

c. Tahap pengamatan (Observasi), Pengamatan dilaksanakan bersamaan dengan kegiatan belajar mengajar. Dan

d. Tahap Refleksi, berdasarkan hasil obesrvasi yang didapat, maka penulis perlu melakukan refleksi dalam pembelajaran yang telah di aplikasikannya di kelas, untuk melihat celah-celah yang menjadi masalah pokok dalam pembelarjaan, sehingga dapat dilakukan perbaikan di kegiatan berikutnya.

Berikut data yang diperoleh dari hasil penelitian pada siklus I, setelah menerapkan pendekan Contextual Teaching Learning (CTL):

\section{Hasil Tes Siswa Pada Siklus I}

\begin{tabular}{|c|l|c|}
\hline No & \multicolumn{1}{|c|}{ Uraian } & Hasil \\
\hline 1 & Nilai rata-rata tes & 70 \\
\hline 2 & Persentasi ketuntasan belajar & $58,62 \%$ \\
\hline 3 & Jumlah siswa yang belajar tuntas & 17 \\
\hline 4 & Jumlah siswa yang tidak tuntas & 12 \\
\hline
\end{tabular}

Dari tabel di atas dapat dijelaskan bahwa dengan menerapkan pendekatan CTL diperoleh nilai rata-rata siswa 70 dan ketuntasan belajar mencapai 58,62\%. Hasil tersebut menunjukkan bahwa pada siklus I secara klasikal belum tuntas, karena siswa yang memperoleh nilai $\geq 70$ belum mencapai $85 \%$. Karenanya perlu dilaksankan siklus II dengan memperhatikan catatan-catatan penting yang diperoleh pada tahap refleksi.

Pada siklus II diperolehlah data berikut sebagai berikut:
Hasil Tes Siswa Pada Siklus II

\begin{tabular}{|c|l|c|}
\hline No & \multicolumn{1}{|c|}{ Uraian } & Hasil \\
\hline 1 & Nilai rata-rata tes & 83,12 \\
\hline 2 & Persentasi ketuntasan belajar & $86,20 \%$ \\
\hline 3 & Jumlah siswa yang belajar tuntas & 25 \\
\hline 4 & Jumlah siswa yang tidak tuntas & 4 \\
\hline
\end{tabular}

Berdasarkan tabel di atas, diperoleh nilai rata-rata tes sebesar 83,12 dari 29 siswa, siswa yang telah tuntas sebanyak 25 siswa, dan 4 siswa belum mencapai ketuntasan belajar. Secara klasikal kutuntasan belajar yang telah dicapai sebesar 86, $20 \%$ termasuk kategori tuntas.

Pada siklus II ini mengalami peningkatan yang sangat baik. Peningkatan hasil belajar pada siklus II dipengaruhi oleh adanya peningkatan kemampuan guru dalam menerapkan pendekatan CTL di kelas, sehingga siswa menjadi lebih aktif dalam mengkonstruk pengetahuan dan lebih termotivasi dalam belajar dengan kelompokkelompok diskusinya sehingga siswa lebih mudah dalam memahami materi yang telah diberikan.

\section{PEMBAHASAN}

1. Ketuntasan Hasil Belajar Siswa

Hasil penelitian yang diperoleh menunjukkan bahwa pembelajaran dengan menggunakan pendekatan Contextual Teaching and Learning memberikan positive impact dalam meningkatkan prestasi belajar siswa.

Hal tersebut dapat dilihat dari semakin baiknya pemahaman siswa terhadap materi yang dipaparkan oleh guru, yang tampak pada ketuntasan belajar yang terus meningkat dari siklus I ke siklus II yaitu masing-masing $58,62 \%$ dan $86,20 \%$.

Dapat pula dilihat, bahwa pada siklus ke-2 ketuntasan belajar siswa secara klasikal telah tercapai.

\section{Prestasi Siswa Dalam Pembelajaran}

Berdasarkan analisis data, diketahui prestasi siswa selama proses belajar mengajar dengan menggunakan pendekatan Contextual Teaching Learning dalam setiap siklus mengalami peningkatan. 
Silviana Maya P.: Penerapan Pendekatan Contextual Teaching And Learning Sebagai Upaya Meningkatkan Prestasi Belajar Matematika Siswa

Hal ini memberikan positive impact terhadap prestasi belajar siswa yaitu ditunjukkan oleh meningkatnya nilai rata-rata siswa pada setiap siklus.

\section{PENUTUP}

\section{Simpulan}

Berdasarkan seluruh pembahasan serta analisis yang telah dilaksanakan dapat ditarik kesimpulan bahwa dengan menggunakan pendekatan Contextual Teaching And Learning dalam pembelajaran dapat meningkatkan prestasi belajar siswa kelas XI KR 2 SMK Negeri 8 Surabaya, yang ditandai dengan peningkatan rata-rata tes dan ketuntasan belajar setiap siklus yaitu pada siklus I nilai rata-rata tes adalah 70 dan pada siklus II adalah 83,12 dan ketuntasan belajar klasikal pada siklus I mencapai 58,62 \% dan pada siklus II mencapai $86,20 \%$.

\section{Saran}

Dalam penelitian ini, ada beberapa saran penulis terkait penelitian ini, diantaranya:

a. Untuk melaksanakan pembelajaran dengan menggunakan pendekatan CTL memerlukan persiapan yang cukup matang agar diperoleh hasil yang optimal., Karenanya, guru harus mampu menentukan topik yang benar dan sesuai sehingga bisa diterapkan dengan pendekatan CTL dalam proses belajar mengajar. b. Pendekatan CTL dapat dipadukan dengan model pembelajaran lainnya sehingga diperoleh model pembelajaran yang lebih sesuai karakteristik pokok bahasan dan kondisi peserta didik.

\section{DAFTAR PUSTAKA}

Arikunto, Suharsimi; Suharjono; dan Supardi. 2008. Penelitian Tindakan Kelas. Jakarta: Bumi Aksara. Arikunto, Suharsimi, 2006. Prosedur Penelitian suatu Pendekatan Praktek, Jakarta : Rineka Cipta.

Depdiknas. 2002. Pendekatan Kontekstual ( Contextual Teaching And Learning ). Jakarta: Dirjen, Didasmen, Direktorat Sekolah Lanjutan Pertama.

Gerson, Tanwey. 2002. Belajar dan Pembelajaran. Surabaya: Unesa University Press.

Nurhadi, Yasin Burhan dan Gerrad Suduk Agus. 2004. Pembelajaran Kontekstual Dan Penerapannya Dalam KBK. Malang.

Ridwan. 2008. Ketercapaian Prestasi Belajar. Tersedia pada http://Ridwan202.word press.com/2008/05/03 Ketercapaian-prestasibelajar. Diakses pada 19 Juni 2010.

Slameto. 2003. Belajar dan Faktor-Faktor Yang Mempengaruhinya. Jakarta: Rineka Cipta.

Suherman, Erman \& Winata Putra, S. Udin. 1992. Strategi Belajar Mengajar Matematika. Modul 1-9. Jakarta : UT. Depdikbud. 